\title{
Anmeldelse:
}

\section{Ny dansk litteratur om EU}

Af Uffe Østergård

To garvede journalister som kender Bruxelles ud og ind, giver hver deres aktuelle bud på, hvad der foregår 'Nede i EU'. Og de vinder ved at blive læst sammen.

Jacob Langvad: Europas svære fællesskab. Columbus 2015, 144 s.

Jens Thomsen: Kommissærens første 100 dage. Gyldendal 2015, 225 s.

Vi er ikke forvænte med seriøs oplysning om EU-samarbejdet på dansk. Der er ganske vist mange dygtige EUspecialister, hvoraf mange er uddannet på European University Institute i Firenze. Men flertallet af forskerne følger Videnskabsministeriets krav om at publicere i specialiserede tidsskrifter på engelsk, eventuelt suppleret med optræden i de elektroniske medier.

Den eneste store undtagelse er den fremragende lærebog Europa i forandring af Marlene Wind, Morten Kelstrup og Dorte Sindbjerg Martinsen fra 2008. Den er ganske vist kommet i en udvidet og opdateret udgave i 2012, men fire år er lang tid, især i europæisk politik i disse år hvor krise efter krise har

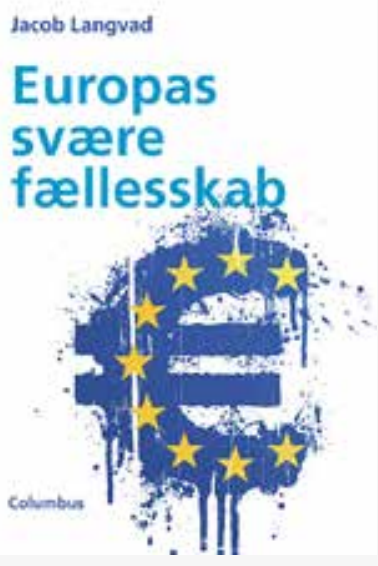

udfordret institutionerne og de indarbejdede samarbejdsmetoder.

Samtidig har vi fået et mere EUskeptisk Europa-Parlament og en ny Kommission, der har lovet at være ambitiøs på store sager og beskeden på små sager. Det er derfor yderst velkomment at to garvede journalister som kender Bruxelles ud og ind nu har givet os hver deres aktuelle bud på hvad der foregår i det, selv for mange politisk interesserede, så fjerne EU. "Nede i EU" som det hedder hos såvel modstandere som de stadig mere lunkne tilhængere.

Uffe Østergård er professor emeritus i europæisk historie, Department for Business and Politics, CBS og adjungeret professor i moderne europæisk historie, Aarhus Universitet 


\section{Mere end en lærebog}

Jacob Langvad er en af de ret få danske journalister som dækker EU professionelt fra Bruxelles, hvor han bor siden 1993. Han har kompetent og velorienteret berettet til Weekendavisen, Mandag Morgen og P1 Orientering i alle årene og har nu samlet sine resultater i en diskret udseende bog om EU på lærebogsforlaget Columbus.

Den er camoufleret som en lærebog i samfundskundskab for gymnasiet, men det skal man ikke lade sig afskrække af. Den har ganske vist opsummeringer og pædagogiske spørgsmål. Men der er først og fremmest tale om en velskrevet, præcis og aktuel redegørelse for det europæiske samarbejde med mange illustrerende historier og satiretegninger.

Reelt har vi her den første helt opdaterede redegørelse for EU's aktuelle situation og de mange kriser der presser fællesskabet, samt en opdateret fortælling om tilblivelsen af den nye Kommission under ledelse af luxembourgeren JeanClaude Juncker i 2014.

Som noget nyt lykkedes det EuropaParlamentet at få valget af Kommission ud i det åbne og væk fra regeringernes sædvanlige aftaler i korridorerne i det Europæiske Råds skumle Justus Lipsius bygning. Den ligger godt nok kun et langt stenkast fra Kommissionens firfløjede Berlaymont bygning på den anden side af rue de la Loi på vejen til Europa parlamentets to imposante bygninger. Men repræsenterer en traditionel mellemstatslig og lukket politisk verden.

Regeringslederne blev imidlertid overhalet af EU-parlamentarikerne der med henvisning til en ulden paragraf $i$
Lissabon-traktaten om at Kommissionen skal udnævnes under hensyn til sammensætningen af Europa-Parlamentet fik introduceret et nyt begreb 'spidskandidater' - med angelsaksisk skadefryd kaldt 'Spitzen-kandidaten' for at understrege det mærkelige tyske krav om demokrati i EU.

Alt dette og meget mere oplyses man kort og klart om hos Jacob Langvad med indlagte småhistorier og skarpe analyser af alt fra Grækenlands underskud til striden med Rusland om Ukraine.

\section{De første 100 dage}

Langvads gode lærebog vinder ved at blive læst sammen med erhvervsjournalisten Jens Thomsens redegørelse for Margrethe Vestagers første tre måneder som EU kommissær for konkurrence. Hendes område er et af de tungeste poster, idet Kommissionen både er efterforsker, anklager og dommer i sager om overtrædelse af den fri konkurrence.

Kommissionens afgørelser kan ganske vist indklages for EU-Domstolen $\mathrm{i}$ Luxembourg. Og bliver det, som i 2002 hvor Kommissionen tabte tre højt profilerede sager. Men magtfuld og administrativt tung er posten. Det får man et levende indtryk af $\mathrm{i}$ Thomsens bog der er baseret på lange interviews med Vestager, suppleret med redegørelser for Juncker-Kommissionens tilblivelse. Han skildrer såvel hendes overraskende exit fra dansk politik, de grundige forberedelse til høringen i Parlamentet - som hun klarede i fin stil - og de første tre måneders arbejde fra indsættelsen 3 . november 2014 til april 2015.

Dertil kommer indslag om hendes ledelsesstil der er mere personlig og mindre hierarkisk end normalt i et EU der 
stadig er præget af fransk forvaltningskultur, selv om sproget helt overvejende er blevet engelsk efter udvidelserne i 1995 og 2004. Hendes nordiske stil illustreres med en beskrivelse af indretningen af kontoret, hvor hun sidder lige ved døren for at kunne tage imod besøgende blot ved at vende sig om.

At bogen fremtræeder som noget i retning af en helgenkåring af Margrethe Vestager som politiker og leder må man tilskrive genren. Det samme gælder de mange gentagelser. For her er vi tættere på dagligdagen i arbejdet i Kommissionen end man ellers kommer i litteraturen. Ingen ved hvordan det vil gå med de tunge retssager hun har indledt mod giganter som Google og Gazprom.

Men indtil videre har hun imponeret verdensoffentligheden. Dog mest uden for Danmark for, som Jens Thomsen skriver, følger danske medier kun med i 'kedelige' emner som konkurrencebe

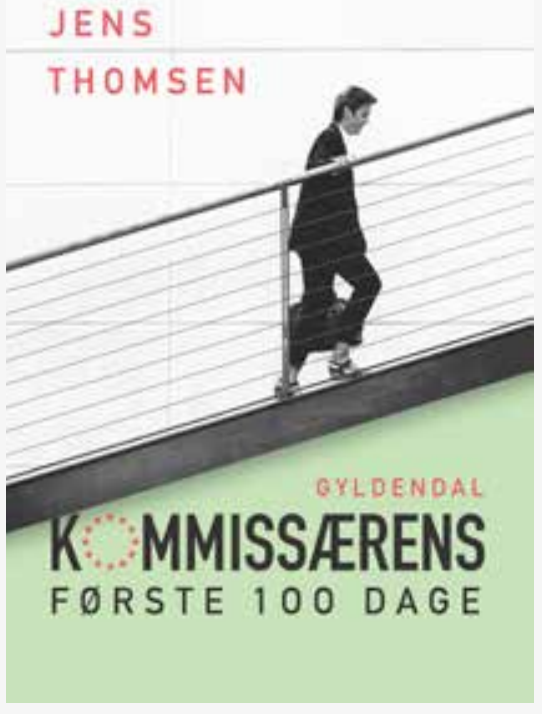

tingelserne på det indre marked gennem lejlighedsvise referater af Economist og Financial Times.

Danskerne går ind for markedssamarbejdet, men hvordan det fungerer i detaljer, overlader vi gladeligt til virksomheder og lobbyister. Livet er som bekendt for kort til EU.

\section{Lakridspiber og krumme agurker}

Skulle man alligevel have lyst til at sætte sig ind i nogle af de finere detaljer er det nu muligt i disse velskrevne og til tider ligefrem spændende bøger. Hos Langvad er der oven i købet blevet plads til et fint kapitel om Bruxelles som by og hovedstad i det splittede land Belgien. Et andet kapitel oplyser om de mange fejlagtige danske myter om EU, fra den misforståede rapport om et forbud mod lakridspiber til reglerne om krumme agurker.

De sidste er blevet til selve sindbilledet på europæisk overregulering, men var i virkeligheden en stor dansk sejr der fik overført danske pakningsregler for agurker til europæisk niveau. Der kan være mange flere af danske gartneres lige agurker i en kasse end sydeuropæiske 'krumme' agurker der er vokset på jorden uden kontrol. Men den sejr var der ingen som ønskede at tage ansvaret for da eksemplet kom frem i kampen om Maastricht-traktaten i 1992.

EU er mange ting, men især detaljer. Det bliver man klogere på i disse bøger, som til gengæld prisværdigt undlader at diskutere de mytologiske forestillinger om 'national suverænitet, der spiller så stor en rolle i argumentationen fra både højre og venstre side af det politiske spektrum. Som til gengæld ikke synes at interessere sig for indflydelse. 